\title{
Implementasi Delapan Fungsi Keluarga di Provinsi Jawa Tengah
}

\author{
Urip Tri Wijayanti, Deybie Yanti Berdame \\ Perwakilan BKKBN Prov Jawa Tengah Jl Pemuda 79 Semarang, Jawa Tengah dan Perwakilan \\ BKKBN Prov Sulut J1. 17 Agustus, Manado, Sulut \\ haidar1602@yahoo.co.id, deybie07@yahoo.co.id
}

Masuk tanggal : 10-10-2018, revisi tanggal : 23-02-2019, diterima untuk diterbitkan tanggal : 23-02-2019

\begin{abstract}
Families contribute to the physical and psychological development of children, families are also very influential on children's achievement. In theory the family has eight family functions ranging from religious functions, socio-cultural, love, protection, reproduction, socialization and education, economics, and environmental development. These eight functions are expected to be a guide for the lives of Indonesian families. Besides that, it is a prerequisite, reference and lifestyle of every family in order to realize a prosperous and quality family. The magnitude of the family's role, the Representative of the Central Java Province BKKBN and the Family Planning Regional Organization (KB OPD) spread in 35 districts/cities do not remain silent in responding to eight family functions, one of which is by socializing to the public. After efforts to socialize, interesting things to study the application of eight family functions, the study aims to: (1) analyze the adolescent reproductive health program, planned family planning, exposure to population information, family planning and adolescent reproductive health and empowerment and family resilience that produce level estimation results provinces, and (2) describe the latest National Medium Term Development Plan (RPJMN) Performance Indicators. The target of the survey is family, namely the wife and husband, but primarily the wife. Family respondents in this survey were 2.275 respondents. Data collection uses structured questionnaires that have been installed on smartphones. The results showed that in general respondents $(88,6 \%)$ never heard / knew about eight family functions. In general application has been implemented even though there are still respondents who do not know. So basically the respondents did not understand the eight family functions but in practice they have implemented. For this reason, it is necessary to socialize eight family functions to families, socialization is carried out by packaging through creative IEC (communication, information and education) so that messages can be conveyed clearly.
\end{abstract}

Keywords: eight of family functions, family planning, health program

\begin{abstract}
Abstrak
Keluarga berkontribusi pada perkembangan fisik maupun psikis anak-anak, keluarga juga sangat berpengaruh pada prestasi anak. Secara teori keluarga memiliki delapan fungsi keluarga mulai dari fungsi agama, sosial budaya, cinta kasih, perlindungan, reproduksi, sosialisasi dan pendidikan, ekonomi, dan pembinaan lingkungan. Delapan fungsi tersebut diharapkan menjadi pedoman kehidupan keluarga-keluarga Indonesia. Selain itu menjadi prasyarat, acuan, dan pola hidup setiap keluarga dalam rangka terwujudnya keluarga sejahtera dan berkualitas. Besarnya peranan keluarga tersebut, maka perwakilan Badan
\end{abstract}


Kependudukan dan Keluarga Berencana Nasional (BKKBN) provinsi Jawa Tengah dan Organisasi Perangkat Daerah Keluarga Berencana (OPD KB) yang tersebar di 35 kabupaten/kota tidak tinggal diam dalam merespons delapan fungsi keluarga, salah satunya dengan mensosialisasikan kepada masyarakat. Setelah upaya mensosialisasikan, hal menarik untuk dikaji penerapan delapan fungsi keluarganya, maka penelitian bertujuan untuk: (1) menganalisis tentang program kesehatan reproduksi remaja, keluarga berencana, keterpaparan informasi kependudukan, KB dan Kesehatan Reproduksi Remaja serta pemberdayaan dan ketahanan keluarga yang menghasilkan estimasi hasil tingkat provinsi, dan (2) mendeskripsikan Indikator Kinerja Rencana Pembangunan Jangka Menengah Nasional (RPJMN) terbaru. Sasaran surveinya keluarga yakni istri dan suami, namun utamanya istri. Responden keluarga dalam survei ini sebanyak 2.275 responden. Pengumpulan data menggunakan kuesioner terstruktur yang sudah terinstal pada smartphone. Hasil penelitian menunjukkan, bahwa secara umum $(88,6 \%)$ responden tidak pernah mendengarkan/mengetahui tentang delapan fungsi keluarga. Dalam penerapannya secara umum sudah menerapkan meskipun masih ada responden yang tidak mengetahui. Intinya, responden tidak memahami delapan fungsi keluarga namun pada prakteknya sudah menerapkan. Untuk itu perlu dilakukan sosialisasi delapan fungsi keluarga pada keluarga-keluarga, sosialisasi dilakukan dengan mengemas melalui KIE (Komunikasi, Informasi dan Edukasi) kreatif agar pesan-pesan dapat tersampaikan secara jelas.

Kata Kunci: delapan fungsi keluarga, keluarga berencana, program kesehatan

\section{Pendahuluan}

Undang-undang nomor 52 tahun 2009 tentang perkembangan kependudukan dan pembangunan keluarga menyatakan keluarga adalah unit terkecil dalam masyarakat terdiri dari suami-istri, suami-istri dan anak, duda dengan anaknya dan janda dengan anaknya. Sebagai unit terkecil sudah seharusnya antar anggota keluargasaling berinteraksi untuk mewujudkan keharmonisan, karena sangatberkontribusi pada perkembangan fisik maupun psikis anak-anak. Seperti pendapat Vygotsky (Nidhomuddin, 2012) anak akan lebih berkembang melalui interaksi dengan orang-orang yang sudah terampil dalam suatu bidang tertentu. Nurytn (Kirom, 2014) menyatakan pentingnya peranan orang dewasa dan anak-anak sebaya dalam mempengaruhi proses perkembangan anak. Pada konteks ini, menurut Alwisol dalam Kirom (2014) keluarga adalah orang dewasa yang pertama kali berinteraksi dengan anak, sehingga peranan keluarga dalam proses perkembangan anak, utamanya belajar sangat penting. Teori lain disampaikan Albert Bandura dalam Kirom (2014) seseorang dapat belajar dari apa yang dilihat. Berlandaskan teori, anak akan belajar dari apa yang dilihat pada lingkungan, sedangkan lingkungan pertama anak adalah lingkungan keluarga, dengan demikian lingkungan keluarga sangat berpengaruh pada prestasi anak.

Besarnya peranan keluarga sebenarnya dapat dilihat dari apa saja fungsi keluarga tersebut. Menurut Badan Kependudukan dan Keluarga Berencana Nasional (BKKBN) fungsi keluarga ada delapan, mencakup agama, sosial budaya, cinta kasih, perlindungan, reproduksi, sosialisasi dan pendidikan, ekonomi, dan pembinaan lingkungan (BKKBN, 2013). Delapan fungsi tersebut diharapkan 
Urip Tri Wijayanti, Deybie Yanti Berdame: Implementasi Delapan Fungsi Keluarga di Provinsi Jawa Tengah

menjadi pedoman kehidupan keluarga-keluarga Indonesia. Selain itu menjadi prasyarat, acuan, dan pola hidup setiap keluarga dalam rangka terwujudnya keluarga sejahtera dan berkualitas (BKKBN, 2016).

Perwakilan BKKBN provinsi Jawa Tengah dan Organisasi Perangkat Daerah Keluarga Berencana (OPD KB) yang tersebar di 35 kabupaten/kota tidak tinggal diam dalam merespons delapan fungsi keluarga, salah satunya dengan mensosialisasikan kepada masyarakat. Sosialisasi dilakukan lewat workshop, seminar dan pelatihan dengan peserta tokoh agama, tokoh masyarakat, tokoh adat, kader-kader KB serta mitra kerja yang konsen pada program-program BKKBN. Harapannya mereka bisa menyampaikan kepada masyarakat.

Setelah upaya mensosialisasikan, hal menarik lainnya untuk dikaji penerapan delapan fungsi keluarganya, maka penelitian bertujuan untuk: (1) menganalisis tentang program kesehatan reproduksi remaja, keluaga berencana, keterpaparan informasi kependudukan, KB dan Kesehatan Reproduksi Remaja serta pemberdayaan dan ketahanan keluarga yang menghasilkan estimasi hasil tingkat provinsi, dan (2) mendeskripsikan Indikator Kinerja Rencana Pembangunan Jangka Menengah Nasional (RPJMN) terbaru.

\section{Metode Penelitian}

Penelitian di desain sebagai survei deskriptif. Survei ini merupakan survei yang berskala nasional. Survei dilakukan setiap tahun sehingga gambaran hasil capaian kinerja bisa dilihat per tahunnya. Pengertian delapan fungsi keluarga, menurut BKKBN (2013) berupa: pertama fungsi agama, keluarga memiliki fungsi agama maksudnya selain orang tua sebagai guru dalam pendidikan anaknya, orang tua juga merangkap sebagai ahli agama. Orang tua tempat mengaji dan membacakan kitab suci dalam membentuk kepercayaan anak-anak mereka. Melalui fungsi agama ini anggota keluarga tahu mana yang boleh dan tidak boleh dilakukan. Kedua fungsi sosial budaya, maksudnya dalam perkembangan anak keluarga memiliki peran penting untuk menanamkan pola tingkah laku berhubungan dengan orang lain (sosialisasi) keluarga juga memberikan warisan budaya, disini terlihat bahwasanya keluarga diangap masyarakat yang paling primer. Warisan budaya sebagai ciri khas suatu bangsa harus dilestarikan, salah satu perwujudan pelestariannya dengan mengajarkan pada generasi-generasi muda.

Ketiga fungsi cinta dan kasih sayang. Pertumbuhan seorang anak tidak akan pernah lepas dari pengaruh keluarganya, peran keluarga begitu sentralistik dalam membetuk kepribadian keturunannya, oleh karena itulah salah satu fungsi keluarga adalah menyalurkan cinta dan kasih sayang. Cinta dan kasih sayang orang tua yang lengkap akan memberikan perkembangan postif luar biasa pada anak-anaknya. Anak-anak akan merasa terpenuhi dalam hal kasih sayang. Keempat fungsi perlindungan, perkembangan anak memerlukan rasa aman, kasih sayang, simpati dari orang lain. Keluarga tempat mengadu, mengakui kesalahankesalahan, dan tempat berlindung bagi anggota keluarga.

Kelima fungsi reproduksi, artinya keluarga merupakan sarana manusia untuk menyalurkan hasrat seksual kepada manusia lain (yang berbeda jenis 
kelamin) secara legal di mata hukum dan sah secara agama, sehingga manusia tersebut dapat melangsungkan hidupnya karena dengan fungsi biologi akan mempunyai keturunan berupa anak. Keenam fungsi sosialisasi dan pendidikan adalah untuk mendidik anak mulai dari awal sampai pertumbuhan anak menjadi dewasa, keluarga berperan penting terhadap upaya terbentuk kepribadian yang baik dari waktu ke waktu, sebelum terjun dalam kehidupan masyarakat yang sebenarnya.

Ketujuh fungsi ekonomi, artinya keluarga menjadi sarana yang baik untuk bertugas memenuhi kebutuhan hidup anggota keluarga di dalamnya, dimana dalam prosesnya fungsi ekonomi ini mampu membagikan kerangka keluarga, misalnya ayah sebagai pencari uang untuk kebutuhan dan ibu bertugas mengurus anak, meskipun saat ini banyak ibu yang sudah masuk dalam ranah kerja namun mereka tidak akan lepas dan lupa akan kewajiban dalam mengurus anak-anaknya. Kedelapan fungsi lingkungan, maksudnya semua bentuk tingkah laku yang dilakukan seorang anggota keluarga awal mulanya dilakukan dalam keluarga. Anak atau anggota keluarga adalah cerminan bagaimana ia bisa menerapkan kesesuaiannya terhadap lingkungan. Memelihara lingkungan dengan baik sangat memberikan kontribusi pada kelangsungan hidup. Upaya untuk menjaga lingkungan bisa dilakukan dari hal kecil mulai dari kebersihan lingkungan, penanaman pohon, dan lain-lain bisa menjadi langkah yang tepat untuk kelangsungan lingkungan.

Pengumpulan data dilakukan bekerjasama dengan Universitas Diponegoro, Semarang. Lokasi survei sudah ditentukan oleh BPS berada di 35 kabupaten/kota di provinsi Jawa Tengah. Kerangka sampel menggunakan pendekatan klaster sebagai enumeration area.Selanjutnya melakukan listing dan mengambil 35 rumah tangga secara random dengan teknik RNG (Random Number Generator). Responden keluarga dalam survei ini sebanyak 2.275 responden. Pengumpulan data menggunakan kuesioner terstruktur yang sudah terinstal pada smartphone.

\section{Hasil Penemuan dan Diskusi}

\section{Karakteristik Responden menurut Jenis Kelamin, Umur dan Status Perkawinan}

Hasil analisis deskriptif dari gambaran responden menurut jenis kelamin, umur dan status perkawinan dapat dijelaskan sebagai berikut.

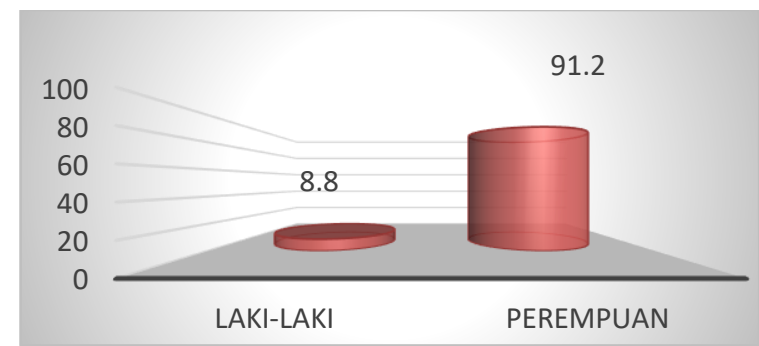

Gambar 1: Persentase Responden Berdasarkan Jenis Kelamin (Sumber: Puslitbang KB \& KS, BKKBN, 2017) 
Urip Tri Wijayanti, Deybie Yanti Berdame: Implementasi Delapan Fungsi Keluarga di Provinsi Jawa Tengah

Secara umum responden berjenis kelamin perempuan $(91,2 \%)$. Hal ini wajar, karena responden utama merupakan istri, kecuali pada saat pengambilan data sasaran responden utama sedang tidak ada ditempat maka diperbolehkan untuk diganti dengan suami. Alasan istri dijadikan sebagai responden utama, karena pertanyaan-pertanyaan kuesioner lebih banyak menanyakan kegiatan yang dilakukan istri, mulai dari pengasuhan dan tumbuh kembang balita, anak dan remaja. Kemudian penggunaan kontrasepsi beserta sumber pelayanan serta delapan fungsi keluarga.

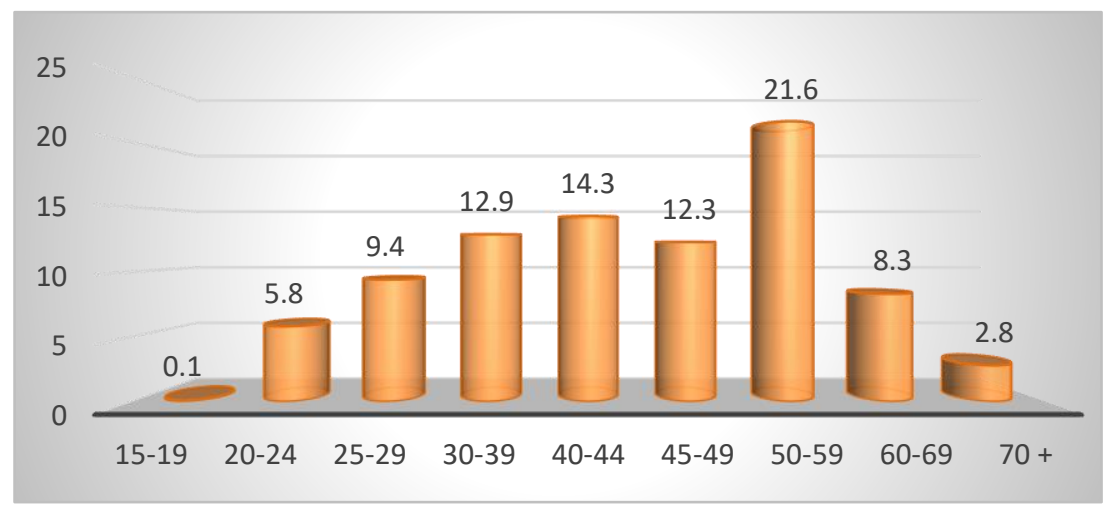

Gambar 2: Persentase Responden Menurut Umur

(Sumber: Puslitbang KB \&KS, BKKBN, 2017)

Persentase terbesar responden berumur 50-59 tahun (21,6\%). Namun, masih ada responden berumur 15-19 tahun $(0,1 \%)$ artinya responden menikah muda dibawah 20 tahun. Hal ini perlu menjadi perhatian khusus bagi BKKBN. BKKBN memiliki program Genre (Generasi Berencana) yang memuat program Pendewasaan Usia Perkawinan (PUP). PUP mewajibkan seorang laki-laki menikah diusia minimal 25 tahun sementara perempuan usia 20 tahun, meskipun Undang-Undang pernikahan Nomor 1 tahun 1974 memperbolehkan perempuan menikah di usia 16 tahun dan laki-laki di usia 19 tahun. Di atas pro-kontra tentang batasan usia menikah satu hal yang penting dipertimbangkan menikah pada usia muda memiliki banyak dampak negatif.

Hasil kajian pakar tentang pernikahan dini menyebabkan kehamilan dan persalinan dini berhubungan dengan angka kematian tinggi dan keadaan tidak normal karena tubuh anak perempuan belum sepenuhnya matang untuk melahirkan (CFRR, 2013). Anak perempuan menghadapi risiko tingkat komplikasi terkait persalinan yang jauh lebih tinggi, seperti fistula obstetri, infeksi, perdarahan hebat, anemia dan eklampsia. Praktik perkawinan dini seringkali menimbulkan dampak buruk terhadap status kesehatan, pendidikan, ekonomi, keamanan anak perempuan dan anak-anak mereka, serta menimbulkan dampak merugikan bagi masyarakat. Perkawinan usia dini juga memiliki dampak antar generasi. Bayi yang dilahirkan memiliki risiko kematian lebih tinggi, dan kemungkinannya dua kali lebih besar untuk meninggal sebelum usia satu tahun dibandingkan dengan anak-anak yang dilahirkan oleh seorang ibu yang telah berusia dua puluh tahunan. Selain itu juga memiliki kemungkinan lebih tinggi 
untuk lahir prematur, dengan berat badan lahir rendah, dan kekurangan gizi. Hal ini berhubungan langsung perempuan menikah yang pada saat kehamilan dan persalinan masih berusia sangat muda, ketika mereka sendiri memiliki tingkat kekurangan gizi yang lebih tinggi dan tubuh mereka belum tumbuh sempurna (Mason et al., 2014). Ketika anak perempuan masih dalam proses pertumbuhan, kebutuhan gizi pada tubuhnya akan bersaing dengan kebutuhan gizi pada janinnya (Fall et al., 2015). Begitu besarnya dampak negatif dari pernikahan dini.Banyak faktor melatarbelakangi terjadinya hal itu mulai faktor ekonomi, pergaulan bebas, kurangnya kontrol orang tua dll.

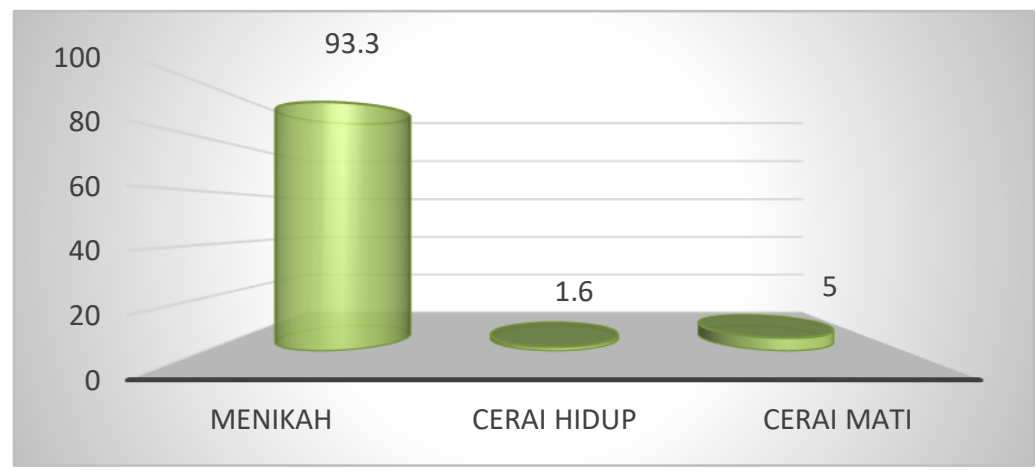

Gambar 3: Persentase Responden Menurut Status Perkawinan (Sumber: Puslitbang KB \& KS, BKKBN, 2017)

Status perkawinan, secara umum berstatus menikah (93,3\%). Maksud status menikah disini yaitu menikah secara resmi yang dilegalkan pada lembaga pemerintah, lembaga keagamaan, atau secara adat.Maka dalam konteks ini menikah siri dan menikah secara adat termasuk pada status menikah.

\section{Persentase Keluarga Menurut Pernah/Tidaknya Mendengar/Mengetahui Delapan Fungsi Keluarga}

Secara umum responden $(88,6 \%)$ tidak pernah mendengarkan/mengetahui tentang delapan fungsi keluarga. Keadaan ini menimbulkan keprihatinan mengingat pemahaman tentang delapan fungsi keluarga sudah sering disampaikan baik melalui materi-materi yang disampaikan pada pelatihan-pelatihan, sosialisasi maupun seminar dengan peserta tokoh-tokoh penggerak di lingkungan masyarakat maupun para pemangku kebijakan yang memiliki akses luas dalam menyampaikan informasi ke masyarakat. Hanya $11,4 \%$ saja responden yang pernah mendengar tentang delapan fungsi. Faktor yang turut berkontribusi kepada hal tersebut tidak terlepas dari kurangnya komunikasi, karena tanpa adanya komunikasi proses sosialisasi tidak akan berlangsung. Mengutip teori komunikasi Harold D Laswell (dalam Wijayanti, 2018) ada lima indikator yaitu who (siapa yang menyampaikan), say what (pesan yang disampaikan), in which channel (media yang digunakan), to whom (kepada siapa ditujukan), dan with what effect (efek/pengaruh). 
Urip Tri Wijayanti, Deybie Yanti Berdame: Implementasi Delapan Fungsi Keluarga di Provinsi Jawa Tengah

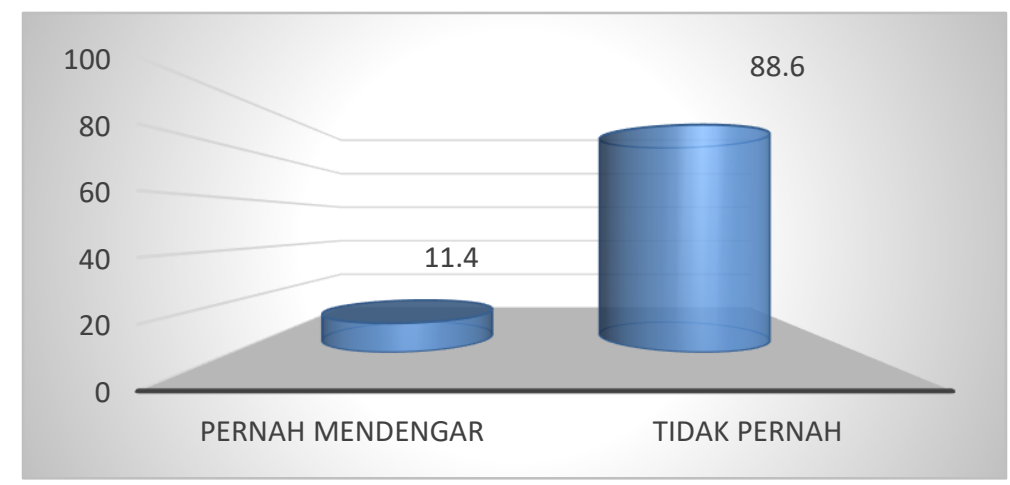

Gambar 4: Persentase Keluarga Pernah/Tidaknya Mendengar/Mengetahui Delapan Fungsi Keluarga (Sumber: Puslitbang KB \& KS, BKKBN, 2017)

Who (siapa yang menyampaikan), siapa yang menyampaikan tertuju pada orang yang memberikan informasi/pesan. Biasanya orang yang menyampaikan dikenal dengan sebutan komunikator. Para komunikator pada saat menyampaikan materi sebaiknya tidak hanya memberikan materi namun harus mampu menjawab semua pertanyaan dari peserta. Pada intinya mereka harus mampu menjadi narasumber atas semua pertanyaan peserta. Selain itu, kemampuan komunikator dalam membawakan materi dengan santai, nyaman dan tidak terkesan menggurui sangatlah diperlukan, agar materi mudah diterima oleh audiens. Komunikator harus mampu mengenai siapa audiensnya, saat berhadapan dengan audiens remaja akan berbeda dengan audiensnya ibu-ibu. Maka dari itu kemampuan komunikator sangatlah diperlukan dalam menyampaikan pemahaman tentang delapan fungsi keluarga.

Kemudian say what (pesan yang disampaikan), pesan yang disampaikan dalam sosialisasi juga harus jelas. Menurut Kim (2013), persyaratan pertama bagi implementasi kebijakan yang efektif adalah bahwa mereka yang melaksanakaan keputusan-keputusan harus mengetahui apa yang harus mereka lakukan. Begitupula pada penyampaian tentang delapan fungsi keluarga, komunikator harus menguasai apa itu delapan fungsi keluarga, kemudian penjabaran masingmasing fungsinya serta implementasi kedelapan fungsi tersebut pada lingkungan keluarga. Sehingga masing-masing anggota keluarga memahami akan fungsi keluarga dan menjadikan keluarga sebagai persemaian yang utama.

Selanjutnya, which channel (media yang digunakan), terkait dengan saluran untuk menyampaikan pesan baik secara langsung maupun tidak langsung. Media bisa cetak maupun elektronik, asalkan media yang digunakan mampu menyampaikan pesan ke sasarannya. Media yang dapat digunakan dalam menyampaikan delapan fungsi keluarga bisa melalui media elektronik, misalnya saja lewat televisi karena sekarang ini hampir seluruh keluarga di perkotaan bahkan pedesaan memiliki televisi.

To whom (kepada siapa ditujukan), kepada siapa ditujukan maka tertuju pada orang yang menerima informasinya, biasanya mereka disebut komunikan. Pada penyampaian delapan fungsi keluarga ditujukan pada keluarga-keluarga beserta anggotanya, keluarga menurut UU No. 52 Tahun 2009 tentang 
Perkembangan Kependudukan dan Pembangunan Keluarga, yang dimaksud dengan keluarga adalah unit terkecil dalam masyarakat yang terdiri dari suami istri, atau suami, istri dan anaknya, atau ayah dan anaknya, atau ibu dan anaknya. With what effect (pengaruh), pengaruh yang dimaksud disini adalah pengaruhnya kepada komunikan/orang yang menerima informasi.Ketika komunikan telah menerima pemahaman tentang delapan fungsi keluarga maka sangatlah diharapkan komunikan bertambah pengetahuannya dan akan berimplikasi pada perilaku mereka. Komunikan akan semakin memahami dan mempraktekan dalam kehidupan keluarganya.

\section{Implementasi delapan fungsi Keluarga}

Implementasi Fungsi Agama. Secara umum keluarga menerapkan fungsi agama berupa ibadah (98\%). Ibadah bagi yang beragama Islam bisa berupa shalat, mengaji dan sebagainya, kemudian bagi agama lain misal agama Kristen ibadah di gereja. Menanamkan ibadah dimulai pada lingkungan keluarga sangatlah penting, mengingat pemahaman tentang baik dan buruk, apa yang boleh dan tidak boleh dalam ajaran agama menjadi bekal bagi individu sepanjang hidupnya. Hal ini sejalan dengan pendapat Soelaeman (1978), keluarga memiliki peranan penting dalam pendidikan agama bagi anak-anaknya, terutama pembentukan kepribadian. Fungsi keluarga ialah fungsi religius. Keluarga berkewajiban memperkenalkan dan mengajak anak serta anggota keluarga lainnya kepada kehidupan beragama. Untuk melaksanakannya, orangtua sebagai tokoh-tokoh inti dalam keluarga itu terlebih dulu harus menciptakan iklim religius dalam keluarga, dan yang dapat dihayati seluruh keluarganya terutama anak-anak (Soelaeman, 1978).

Penerapan fungsi agama selanjutnya, berbuat baik (menolong orang lain) sebanyak $43,7 \%$ responden menjawab hal tersebut, kemudian toleransi terhadap agama lain (19,5\%). Penanaman toleransi terhadap agama lain sangatlah penting karena dengan bekal toleransi yang sudah ditanamakan sejak dini akan memperkuat persatuan dan kesatuan bangsa. Menghormati agama lain diperlukan agar terwujud kehidupan yang harmonis. Penerapan berikutnya ada sebanyak $12,1 \%$ menjawab sabar dan ikhlas akan semua yang sudah ditetapkan oleh Tuhan. Namun ada sebanyak $0,2 \%$ responden tidak tahu dalam menerapkan fungsi agama di kehidupan keluarganya. Ini menjadi perhatian dan masih perlunya menyosialisasikan delapan fungsi agama pada penerapan nilai agama.

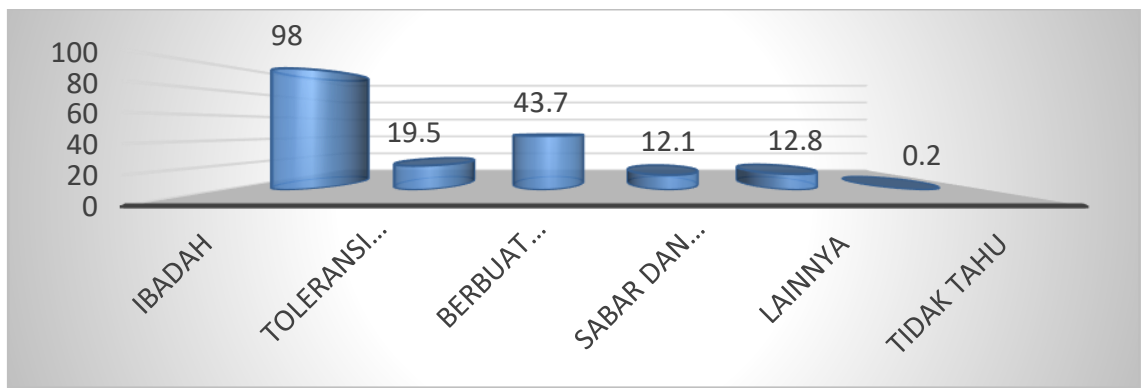

Gambar 5: Persentase Keluarga Menurut Pemahaman dan Kesadaran Menanamkan Nilai-Nilai Fungsi Agama Dalam Lingkungan Keluarga (Sumber: Puslitbang KB \& KS, BKKBN, 2017) 
Urip Tri Wijayanti, Deybie Yanti Berdame: Implementasi Delapan Fungsi Keluarga di Provinsi Jawa Tengah

Fungsi Sosial Budaya. Pada penerapan nilai-nilai sosial budaya dalam lingkungan keluarga sebanyak $62 \%$ keluarga menerapkan nilai tersebut dengan gotong royong. Gotong royong merupakan budaya bangsa Indonesia, budaya ini menerapkan pekerjaan dikerjakan secara bersama-sama, hal ini menjadikan pekerjaan yang susah menjadi ringan. Budaya juga meningkatkan kerukunan baik antar anggota keluarga maupun dengan keluarga lainnya. Budaya ini juga menjadikan Indonesia dipuji oleh bangsa lain. Meskipun budaya gotong royong dalam lingkungan masyarakat saat ini sudah hampir punah tergerus oleh budaya masyarakat yang penuh individual, namun satu hal yang wajib budaya gotong royong harus tetap ada di dalam lingkungan keluarga.

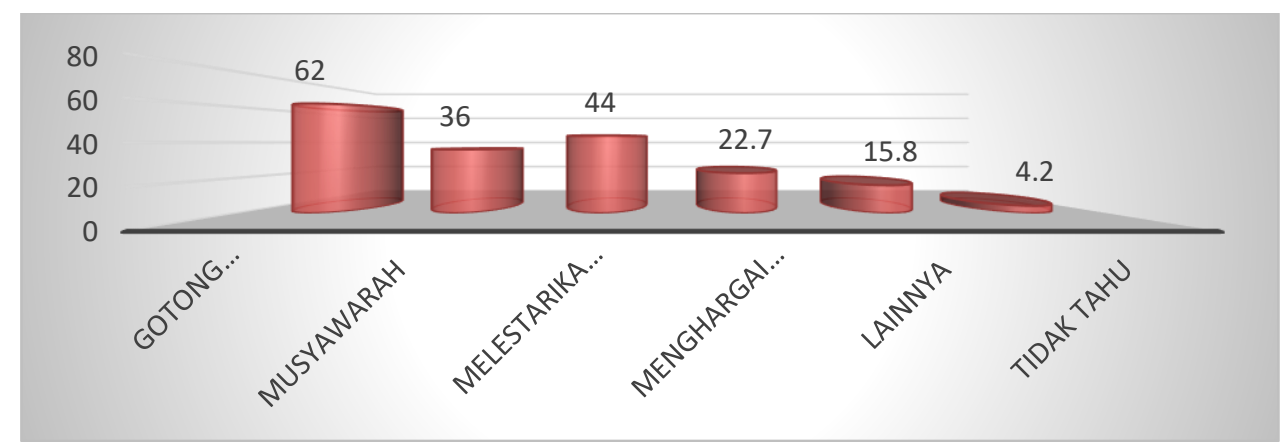

Gambar 6: Persentase Keluarga Menurut Pemahaman Dan Kesadaran Menanamkan Nilai-Nilai Fungsi Sosial Budaya Dalam Lingkungan Keluarga (Sumber: Puslitbang KB dan KS, BKKBN. 2017)

Penerapan nilai sosial budaya berikutnya adalah melestarikan budaya daerah/adat istiadat sebanyak (44\%). Budaya daerah memang wajib dilestarikan agar tidak punah, sehingga anak cucu mengenal budaya yang menjadi warisan nenek moyang. Pelestarian budaya daerah yang dimulai dari lingkungan terkecil yaitu, keluarga menjadi sangat efektif mengingat sudah sejak dini anak-anak diajarkan akanbudaya daerahnya. Penerapan nilai sosial budaya selanjutnya yaitu dengan musyawarah $(36 \%)$. Penerapan musyawarah dalam keluarga menjadi sangatlah efektif baik untuk memecahkan masalah yang ada maupun semakin mendekatkan antar anggota keluarga sehingga semakin menambah keharmonisan dalam keluarga.

Penerapan nilai sosial budaya berikutnya yaitu dengan menghargai antar suku dan golongan sebanyak $22,7 \%$ dan lainnya sebesar $15,8 \%$. Namun sangat disayangkan masih ada sebesar $4,2 \%$ responden yang tidak tahu dalam penerapan fungsi sosial budaya, hal ini menjadi perhatian dan perlu adanya KIE (Komunikasi, Informasi dan Edukasi) yang semakin intens dan meluas pada masyarakat tentang delapan fungsi keluarga dan penerapannya.

Fungsi Cinta Kasih. Perwujudan cinta kasih dalam lingkungan keluarga dilakukan dengan berbagai cara. Secara umum keluarga mewujudkan dengan menunjukkan kasih sayang (69,6\%). Kasih sayang bisa kasih sayang kepada pasangan, pasangan kepada anak maupun antar anak. Selanjutnya sebanyak 63,4\% mewujudkan cinta kasih dalam keluarga dengan menjaga keharmonisan keluarga. Keharmonisan keluarga yaitu, keluarga yang rukun berbahagia, tertib, disiplin, 
saling menghargai, penuh pemaaf, tolong menolong dalam kebajikan, memiliki etos kerja yang baik, bertetangga dengan saling menghormati, taat mengerjakan ibadah, berbakti pada yang lebih tua, mencintai ilmu pengetahuan dan memanfaatkan waktu luang dengan hal yang positif dan mampu memenuhi dasar keluarga (Basri, 2004) terjaganya keharmonisan keluarga akan berimbas pada perdamaian pada lingkungan masyarakat. Sehingga mampu meminimalisir kerusuhan.

Perwujudan cinta kasih selanjutnya dengan tidak pilih kasih/adil ada sebanyak 38\% responden menjawab hal tersebut. Tidak pilih kasih/adil kepada semua anak dalam anggota keluarga akan berdampak besar pada perkembangan mental anak. Seperti hasil penelitian dari peneliti University of Toronto, McMaster University, dan University of Rochester yang melakukan sebuah penelitian dengan mempelajari efek dari sikap orangtua yang pilih kasih diantara anak-anaknya dengan kesehatan mental seluruh keluarga (Vit, 2013). Hasil penelitian menemukan bahwa anak-anak yang kurang mendapatkan kasih sayang atau mendapatkan perlakukan yang sedikit berbeda dari saudara kandungnya, lebih mungkin mengalami masalah kesehatan mental dari waktu ke waktu daripada saudaranya yang mendapat perlakuan yang lebih baik. Peneliti juga menemukan bahwa efek buruk terhadap kesehatan mental tersebut juga dirasakan oleh saudara-saudara kandung yang lain dalam keluarga (Vit, 2013). Keluarga yang pilih kasih terhadap anak-anaknya cenderung memiliki anak-anak yang mudah mengalami masalah kesehatan mental dibanding keluarga lain yang lebih adil dalam membagi kasih sayang (Vit, 2013). Berdasarkan hasil penelitian tersebut sudah seharusnya para orang tua tidak pilih kasih kepada anak-anaknya, semuanya adalah anugrah Tuhan yang harus diperlakukan sama dan adil. Ukuran adil tentunya dengan melihat kemampuan dan umur sang anak.

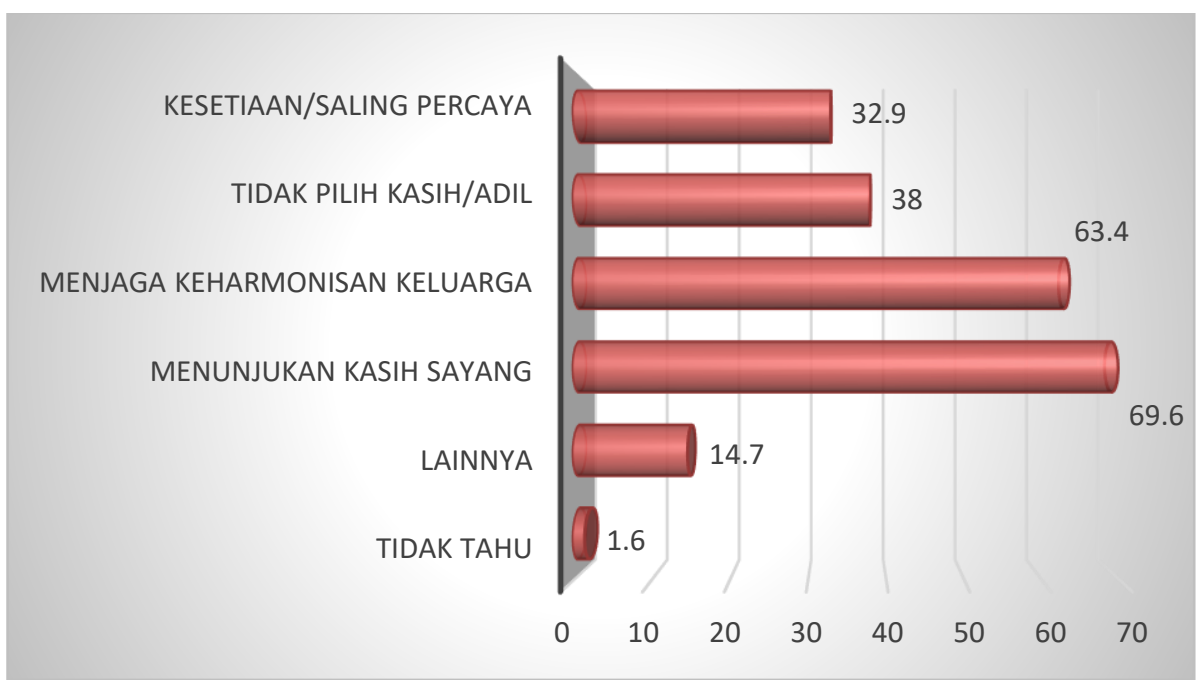

Gambar 7: Persentase Keluarga Menurut Pemahaman Dan Kesadaran Menanamkan Nilai-Nilai Fungsi Cinta Kasih Dalam Lingkungan Keluarga (Sumber: Puslitbang KB \& KS, BKBN, 2017) 
Urip Tri Wijayanti, Deybie Yanti Berdame: Implementasi Delapan Fungsi Keluarga di Provinsi Jawa Tengah

Perwujudan cinta kasih berikutnya dengan kesetiaan/saling percaya $(32,9 \%)$. Kesetiaan ini penting dalam hubungan keluarga terutama dengan pasangan untuk meminimalisir terjadinya ketidakharmonisan dalam keluarga.Apa lagi bagi pasangan yang terpisah jarak baik karena alasan pekerjaan, orang tua maupun lainnya, kesetiaan menjadi teramat penting. Perwujudan cinta kasih selanjutnya sebesar14,7\% menjawab lainnya dan masih ada responden yang tidak tahu sebesar 1,6\%. Maka dari itu masih perlu adanya penguatan KIE tentang delapan fungsi keluarga bagi masyarakat, mengingat masih ada masyarakat yang tidak tahu perwujudan cinta kasih dalam keluarga mereka.

Fungsi Perlindungan. Penerapan nilai-nilai fungsi perlindungan dalam lingkungan keluarga sebanyak $56,1 \%$ responden menjawab melakukan perlindungan non fisik. Perlindungan non fisik dapat berupa tidak berkata kasar pada anak maupun pasangan, tidak membentak, tidak memaki, dst. Kemudian sebanyak 50,3\% responden menjawab perlindungan fisik. Perlindungan ini berupa menggandeng anak ketika jalan bersama. Perilaku menggandeng anak akan memberikan rasa aman bagi anak. Kemudian mengandeng pasangan akan semakin menambah keharmonisan dalam berumah tangga. Perlindungan non fisik lainnya dapat berupa memeluk anak maupun pasangan. Selanjutnya penerapan nilai-nilai perlindungan lainnya berupa pemenuhan kebutuhan keluarga $(42,4 \%)$ responden melakukannya. Pemenuhan kebutuhan keluarga mulai dari sandang, pangan maupun papan. Pemenuhan kebutuhan sandang tidak harus setiap hari baru, asalkan bersih dan masih layak sangatlah bermanfaat dalam melindungi tubuh dari serangan-serangan virus yang dapat mengganggu tubuh.

Perlindungan selanjutnya adalah perlindungan kesehatan $(41,8 \%)$. Perlindungan kesehatan dapat berupa saat sakit diobati atau meminum obat, menghindari hal-hal yang bisa mendatangkan penyakit dst. Dari perlindunganperlindungan yang dilakukan oleh responden ada yang masih perlu mendapatkan perhatian, sebab ada $2.7 \%$ responden tidak tahu dalam perwujudan perlindungan pada keluarganya.

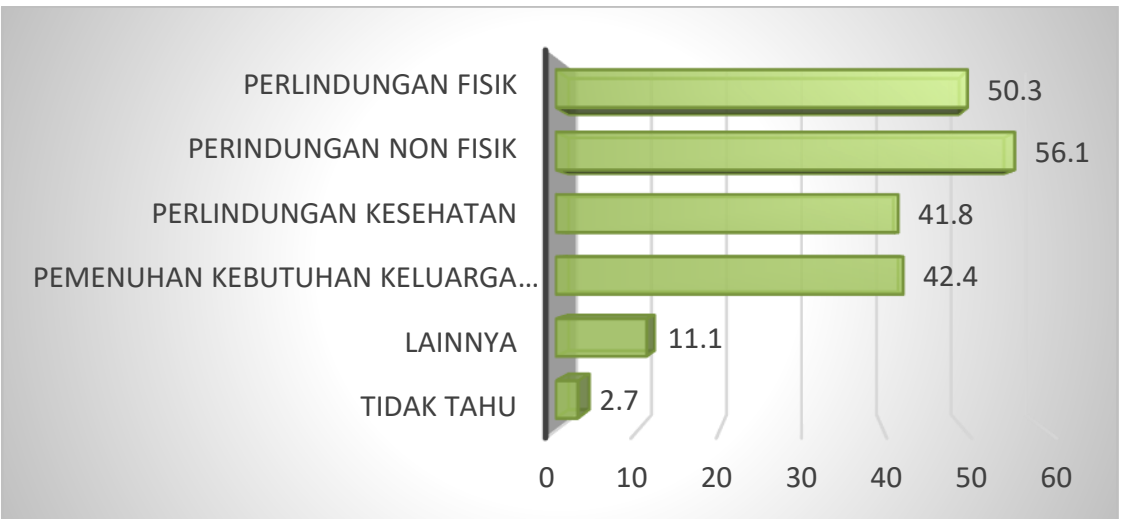

Gambar 8: Persentase keluarga menurut pemahaman dan kesadaran menanamkan nilai-nilai fungsi perlindungan dalam lingkungan keluarga

(Sumber: Puslitbang KB \& KS, BKKBN, 2017) 
Fungsi Reproduksi. Secara umum penanaman nilai-nilai fungsi reproduksi dalam lingkungan keluarga dilakukan dengan menjaga kebersihan organ reproduksi $(53,9 \%)$. Kemudian $48,3 \%$ dengan menghindari pergaulan bebas. Sebab pergaulan bebas sendiri bisa menjerumus pada HIV dan AIDS yang sampai saat ini belum ada obatnya. Keluarga juga menerapkan pendidikan kesehatan reproduksi $(25,5 \%)$, pendewasaan usia perkawinan $(14,7 \%)$. Namun masih ada keluarga yang tidak tahu $(10,6 \%)$ untuk menerapkan dan menanamkan nilai-nilai fungsi reproduksi pada keluarganya.

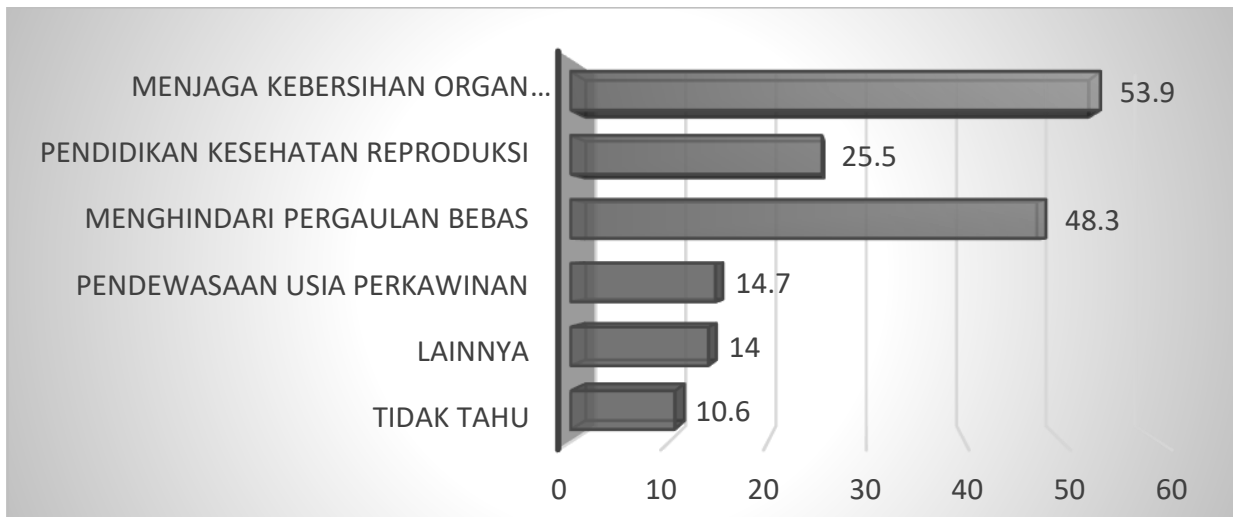

Gambar 9: Persentase Keluarga Menurut Pemahaman Dan Kesadaran Menanamkan Nilai-Nilai Fungsi Reproduksi Dalam Lingkungan Keluarga (Sumber: Puslitbang KB \& KS, BKKBN, 2017)

Fungsi Sosialisasi dan Pendidikan. Menyekolahkan dan mengursuskan anak menjadi penanaman nilai-nilai fungsi sosialisasi dan pendidikan yang paling banyak dilakukan oleh keluarga (87,9\%). Hal ini memperlihatkan bahwa keluarga sudah sadar pentingnya pendidikan bagi anak-anaknya. Ketika materi yang didapat pada lembaga pendidikan yakni sekolah dirasa masih kurang, keluarga menambahnya dengan mengursuskan pada tempat-tempat kursus yang relevan. Sebab teori harus seimbang dengan praktek, ini penting menjadi bekal anak-anak untuk masa depannya. Namun sayangnya masih ada satu persen keluarga yang belum tahu untuk menerapkan nilai-nilai fungsi sosialisasi dan pendidikan. Hal ini harus mendapatkan perhatian agar para keluarga mampu merencanakan pendidikan yang terbaik bagi anak-anaknya. 
Urip Tri Wijayanti, Deybie Yanti Berdame: Implementasi Delapan Fungsi Keluarga di Provinsi Jawa Tengah

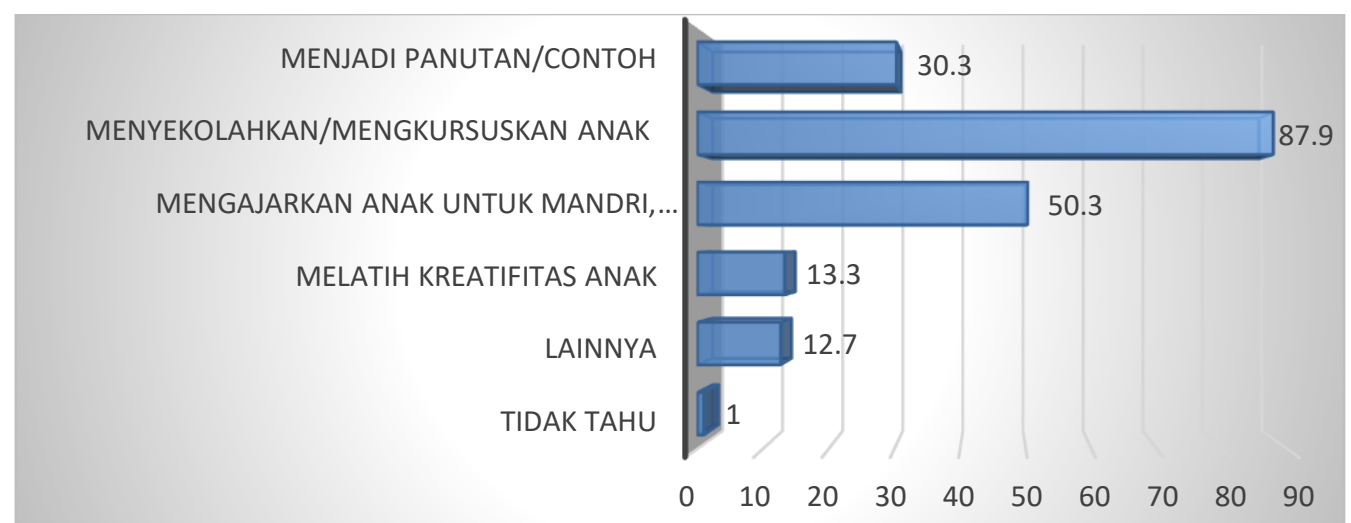

Gambar 10: Persentase Keluarga Menurut Pemahaman dan Kesadaran Menanamkan Nilai-Nilai Fungsi Sosialisasi dan Pendidikan Dalam Lingkungan Keluarga (Sumber: Puslitbang KB \& KS, BKKBN, 2017)

Fungsi Ekonomi. Secara umum keluarga memahami dan menanamkan nilai-nilai ekonomi dalam keluarga dengan menabung $(91,8 \%)$. Budaya menabung yang diterapkan sejak dini menjadikan anak berbudaya hemat. Tidak mengherankan apabila 67,6\% menerapkan hemat (tidak boros) sebagai kelanjutan dari menabung. Namun masih saja ada keluarga yang belum tahu dalam menerapkan fungsi ekonomi $(0,3 \%)$.

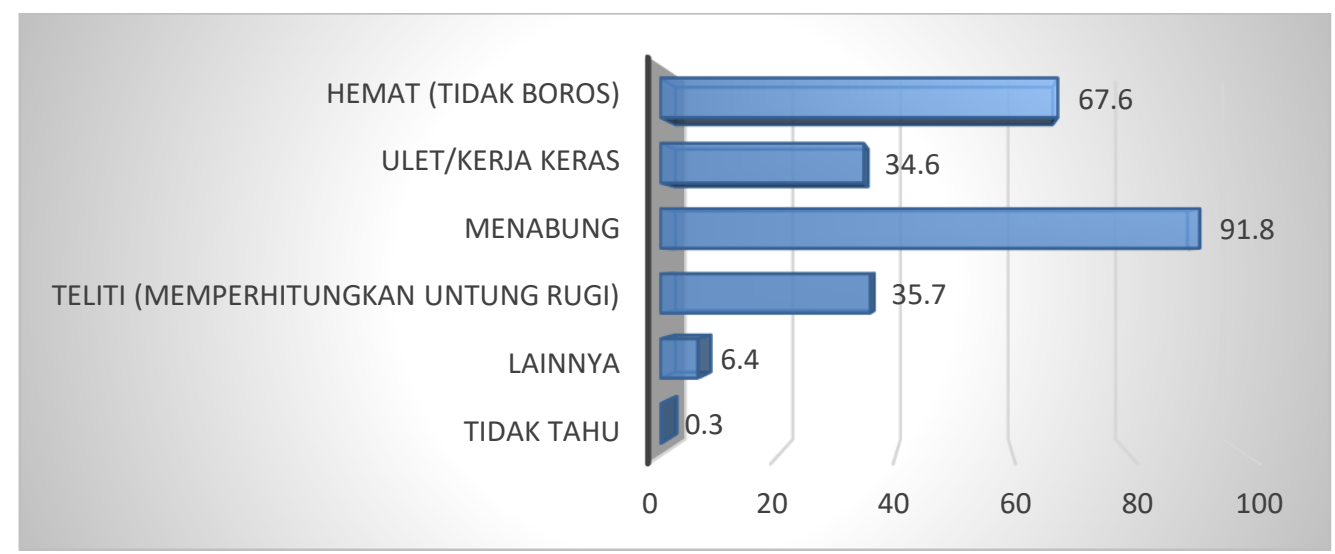

Gambar 11: Persentase Keluarga Menurut Pemahaman dan Kesadaran Menanamkan Nilai-Nilai Ekonomi Dalam Lingkungan Keluarga

(Sumber: Puslitbang KB \& KS, BKKBN, 2017)

Fungsi Lingkungan. Secara umum keluarga menerapkan fungsi lingkungan dengan membersihkan lingkungan sekitar (86,5\%). Membersihkan bisa dilakukan dengan menyapu. Kemudian, 68,9\% melakukan dengan tidak membuang sampah sembarangan. Namun masih ada yang tidak tahu (sekitar $0,4 \%$ ) bagaimana merawat lingkungan yang bersih dan lestari. 


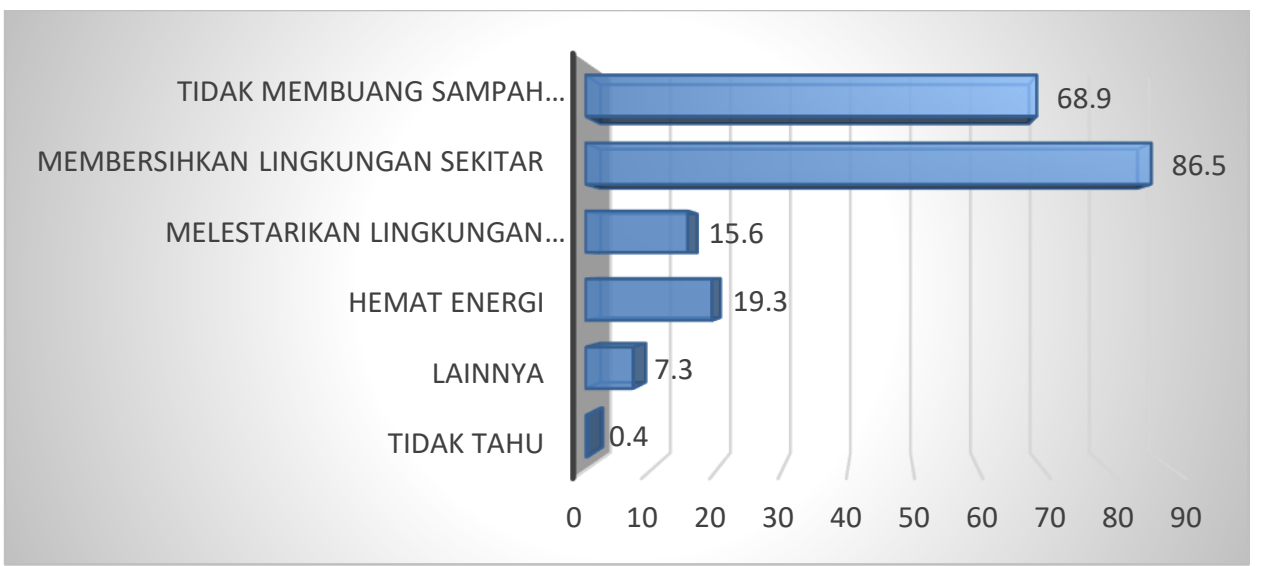

Gambar 12: Persentase Keluarga Menurut Pemahaman Dan Kesadaran Menanamkan Nilai-Nilai Fungsi Lingkungan Dalam Keluarga (Sumber: Puslitbang KB \& KS, BKKBN, 2017)

\section{Simpulan}

Umumnya responden tidak pernah mendengarkan/mengetahui tentang delapan fungsi keluarga. Dalam penerapannya secara umum sudah menerapkan meskipun masih ada responden yang tidak tahu.Intinya, responden tidak memahami delapan fungsi keluarga namun pada prakteknya sudah menerapkan. Perlu dilakukan sosialisasi delapan fungsi keluarga kepada masyarakat, sosialisasi dilakukan dengan mengemas melalui KIE (Komunikasi, Informasi dan Edukasi) kreatif agar pesan-pesan dapat tersampaikan secara jelas.

\section{Ucapan Terima Kasih}

Penulis mengucapkan terima kasih kepada Kepala Perwakilan BKKBN Provinsi Jawa Tengah Wagino, SH, M.Si yang memberikan kesempatan kepada penulis untuk menggunakan data hasil Survei RPJMN Tahun 2017. Ucapan terima kasih pula untuk para enumerator, supervisor dan Tim Manajemen Data BKKBN Pusat atas kerjasamanya dalam pengumpulan data.

\section{Daftar Pustaka}

Basri, Hasan. (2004). Merawat Cinta Kasih. Yogyakarta: Pustaka Pelajar Offset. BKKBN (Badan Kependudukan dan Keluarga Berencana Nasional). (2013). Program Genre dalam Penyiapan Kehidupan Berkeluarga bagi Remaja Ditinjau dari Aspek Delapan Fungsi Keluarga. Jakarta: BKKBN Pusat.

BKKBN (Badan Kependudukan dan Keluarga Berencana Nasional). (2016). Laporan Survei Kinerja Indikator RPJMN Tahun 2016. Jakarta: BKKBN Pusat.

CFRR (Centre for Reproductive Rights). (2013). Accountability for Child Marriage: Key U.N. Recommendations to Governments in South Asia on Reproductive Health and Sexual Violence (Fact Sheet). New York: CFRR. , p. 4. 
Urip Tri Wijayanti, Deybie Yanti Berdame: Implementasi Delapan Fungsi Keluarga di Provinsi Jawa Tengah

Kim, M. et al. (2013). When do laws matter? National minimum-age-of-marriage laws, child rights, and adolescent fertility 1989-2007.Law \& Society Review, 47(3): 589-591.

Fall, Caroline H. D., Harshpal Singh Sachdev, Clive Osmond, et al. (2015). Association between maternal age at childbirth and child and adult outcomes in the offspring: A prospective study in five low-income and middle-income countries (COHORTS collaboration). Lancet Glob Health. 3: e366-377.

Kirom, Anwar. (2014). Pengaruh Keharmonisan Keluarga terhadap Prestasi Belajar Anak. diakses $22 \quad$ September 2018. https://www.academia.edu/27919458/ pengaruh_keharmonisan_keluarga_terhadap_prestasi_anak.

Mason JB, Shrimpton R, Saldanha LS, Ramakrishnan U, Victora CG, Girard AW, et al. (2014). The first 500 days of life: policies to support maternal nutrition. Global Health Action, 7..; and Prentice, A.M. et al. (2013).Critical windows for nutritional interventions against stunting.American Journal of Clinical Nutrition. 97(5): 911-918.

Nidhomuddin. (2012). Pandangan Vygotsky tentang Perkembangan Kognitif. diakses 23 September 2018. https://nidhomuddin01.wordpress.com/2012 /12/19/pandangan-vygotsky-tentang-perkembangan-kognitif/.

Soelaeman, M.I. (1978). Pendidikan Dasar Keluarga. Bandung: IKIP.

Vit. (2013). Orang Tua yang Pilih Kasih Pengaruhi Kesehatan Mental Seluruh Keluarga. Diakses 18 September 2018. https://health.detik.com/beritadetikhealth/d-2174405/orang-tua-yang-pilih-kasih-pengaruhi-kesehatanmental-seluruh-keluarga.

Wijayanti, Urip Tri. (2018). Kendala-Kendala BKB (Bina Keluarga Balita) Holistik Integratif di Provinsi Sulawesi Utara. Jurnal Komunikasi. 10(1): 65-76.

https://journal.untar.ac.id/index.php/komunikasi/article/view/205/1272 